\title{
On the Categories of Possibility, Limiting Conditions and the Qualitative Development Stages of Matter in the Thought of Friedrich Engels
}

\author{
Klaus Fuchs-Kittowski
}

\section{Leibniz-Sozietät der Wissenschaften, Berlin, Germany, fuchs-kittowski@t-online.de}

\begin{abstract}
The contradictory character of matter is the starting point of Friedrich Engels's dialectical principles. Matter can move itself, thus producing ever new possibilities of development and gradually leading to the formation of qualitatively higher forms of movement of matter. In this dialectical conception of development, the explanation of qualitative change is fundamental. Starting from the understanding that the inner contradiction is the source of development and its potential, the transition to a new quality is verifiable. Probabilistic laws are the expression of the unity of necessity and chance in the real possibility. Limiting conditions, like specific structures, informational coupling and whole-part relationships and selection processes, restrict the field of possibilities opened by physical laws. This restriction of possibilities on the lower level opens up new possibilities of development on the higher level, where the transition to a new quality is realised. Materialist and dialectical thinking is the important basis of a theory of biology that is neither physicalist nor vitalist, of a theory of computer science that is neither physicalist nor dualist. Mechanistic thinking - reductionism, the denial of the specific qualities of the different forms of movement of matter - leads to philosophies that reduce the human being to an animal or computer and is both dangerous and inhuman. Computer science needs to engage with the history and application of materialistic and dialectical thinking. It needs to grasp the dialectical unity of similarity and difference between automaton and human in the concrete process of digitalisation and automation. It must overcome the widespread, increasing interest in reducing the human being to an automaton, in order to maintain the unique quality of the human being. It must protect and enhance the special qualities and abilities of human beings. The danger of anti-dialectical thinking, of modern forms of reductionism and the possibility, indeed necessity, of creating a better society, free from profit, greed and war is discussed in this paper in the context of Engels's 200th birthday.
\end{abstract}

Keywords: movement of matter, evolution, development, materialistic and dialectical thinking, mechanistic thinking, specific quality, possibilities, limiting conditions, Friedrich Engels

\section{Internal Contradictions of Matter as the Source of Development}

The contradictory character of matter enables it to move and structure itself, producing ever new possibilities for development. This gradually leads to the formation of qualitatively higher forms of movement of matter and is the starting point of Friedrich Engels's dialectical principles. In the dialectical concept of development, qualitative change is fundamental. Today - because of the findings of quantum physics, the theory of dissipative structures, self-organisation theory, and modern systems theory we can speak in much greater detail about the emergence of the human mind. We can describe more precisely the concept of "possibility" as it has been developed in the modern natural sciences and philosophy. Thus, the transition from one form of movement of matter to another, creating a qualitatively higher form, can be understood with greater precision. The inner contradiction is a source of ever new possibilities of de- 
velopment: understanding the probabilistic laws of quantum physics as a unity of necessity and chance in the real possibility means that new things can appear in nature. Limiting conditions such as specific structures, informational couplings, and the effects of the whole on the development of its parts, restrict the field of possibilities and enable higher forms of the organisation of matter to be formed and with that the transition to a new quality. The development of higher forms of organisation is the prerequisite for new, qualitatively higher forms of the movement of matter in Engels's sense.

\section{A Stage Model of Evolution}

The Stage Model of Evolution (Wahl 2012, 15; see Figure 1) connects the basic ideas presented in the evolutionary step model of information (Fuchs-Kittowski 1997, 551570; Fuchs-Kittowski 1992, 416-432) with Engels's concept of qualitatively different forms of the movement of matter. The scheme sets out the development potentials and interactions or characteristics underlying evolution.

According to Engels, the process of development on our earth led to qualitatively different forms of the movement of matter. Nikolai Hartmann (1935-1950) explains development in the form of new, different stages of being. This differentiation between qualitatively different forms of the movement of matter that arose during evolution represented important progress in philosophical ontology. Whereas previously the focus had been on finding a uniform being, this was now abandoned.

Understanding the changed ontology of classical physics is essential. In classical thinking about physics, the past determines everything - everything is pre-determined. Since the past cannot be changed, neither can the future. All human activity and desire are ultimately no more than an accompaniment of a predestined event. This is a deeply pessimistic world view. Quantumphysics was by contrast hugely liberating in its recognition of objective chance, in unity with necessity - that is, in its probabilistic laws. Philosophy needs to see the potentiality of matter, liberation from pre-determination, and the openness of the future (Fuchs-Kittowski 1976).

Engels offered philosophers and natural scientists a valuable orientation for such insights. He wrote:

cause and effect are conceptions which only hold good in their application to individual cases; but as soon as we consider the individual cases in their general connection with the universe as a whole, they run into each other, and they become confounded when we contemplate that universal action and reaction in which causes and effects are eternally changing places, so that what is effect here and now will because there and then, and vice versa (Engels 1925, 23). 


\begin{tabular}{|c|c|c|c|c|c|c|c|}
\hline & Special Laws & Role of Information & $\begin{array}{l}\text { Relation Hu- } \\
\text { mans-Environ- } \\
\text { ment }\end{array}$ & $\begin{array}{l}\text { Mode of Re- } \\
\text { production }\end{array}$ & Variability & Value/Purpose & $\begin{array}{l}\text { Subjec- } \\
\text { tivity, } \\
\text { Self- } \\
\text { hood }\end{array}$ \\
\hline $\begin{array}{l}\text { Socio-Psy- } \\
\text { chological } \\
\text { Sphere }\end{array}$ & $\begin{array}{l}\text { relation of productive forces } \\
\text { and relations of production, } \\
\text { base/super-structure, inter- } \\
\text { nal and external behaviour }\end{array}$ & $\begin{array}{l}\text { culture, consciousness, } \\
\text { language, thinking, in- } \\
\text { formation from the re- } \\
\text { mote realm of pragmat- } \\
\text { ics }\end{array}$ & work & $\begin{array}{l}\text { development of } \\
\text { production, cul- } \\
\text { tural heritage, } \\
\text { socialisation }\end{array}$ & $\begin{array}{l}\text { historical con- } \\
\text { sciousness, } \\
\text { creativity, } \\
\text { learning }\end{array}$ & $\begin{array}{l}\text { conscious norms, } \\
\text { value system, } \\
\text { purposes }\end{array}$ & $\begin{array}{l}\text { persons, } \\
\text { society }\end{array}$ \\
\hline Biology & $\begin{array}{l}\text { dynamic equilibrium, evolu- } \\
\text { tion, information }\end{array}$ & $\begin{array}{l}\text { stimulus-response, ge- } \\
\text { netic information, infor- } \\
\text { mation from the close } \\
\text { realm of semantics }\end{array}$ & $\begin{array}{l}\text { Metabolism and } \\
\text { information-ex- } \\
\text { change, immune } \\
\text { system }\end{array}$ & $\begin{array}{l}\text { Autopoiesis, } \\
\text { cell division, } \\
\text { genetic mate- } \\
\text { rial, }\end{array}$ & $\begin{array}{l}\text { Mutation, } \\
\text { learning, se- } \\
\text { lective learn- } \\
\text { ing }\end{array}$ & $\begin{array}{l}\text { Selection of val- } \\
\text { ues, purposes, } \\
\text { norms, and val- } \\
\text { ues }\end{array}$ & $\begin{array}{l}\text { Individu- } \\
\text { als, } \\
\text { cell- } \\
\text { units, } \\
\text { species }\end{array}$ \\
\hline Chemistry & $\begin{array}{l}\text { Constant mass relation- } \\
\text { ship, chemical equilibrium, } \\
\text { RGT rule }\end{array}$ & $\begin{array}{l}\text { Signal, potential infor- } \\
\text { mation, syntax }\end{array}$ & & & & & none \\
\hline Physics & $\begin{array}{l}\text { Laws of conservation, four } \\
\text { basic forces, relativity the- } \\
\text { ory, quantum theory }\end{array}$ & no Information & $\begin{array}{l}\text { Dissipative struc- } \\
\text { tures, phase } \\
\text { transition, sym- } \\
\text { metry breaks }\end{array}$ & & & & none \\
\hline
\end{tabular}

Figure 1: Stage Model of Evolution, created by Klaus Fuchs-Kittowski and Dietrich Wahl 
These processes and methods of thinking do not fit into the framework of metaphysical thinking. For dialectical philosophy, on the other hand, because it understands things and their conceptual images essentially in their context - their interconnections, their movement, their emergence and passing - processes are the confirmation of their own method. Engels writes:

Nature is the proof of dialectics, and it must be said for modern science that it has furnished this proof with very rich materials increasing daily, and thus has shown that, in the last resort, nature works dialectically and not metaphysically; that she does not move in the eternal oneness of a perpetually recurring circle but goes through a real historical evolution. In this connection Darwin must be named before all others. He dealt the metaphysical conception of Nature the heaviest blow by his proof that all organic beings, plants, animals, and man himself, are the products of a process of evolution going on through millions of years (Engels 1925, 633).

For Engels, who developed dialectical thinking and made it fruitful especially for the natural sciences, ultimately only necessary development happens. Chance remains in the end only an appearance. With his famous pea example (Engels 1925, 499) he does indeed acknowledge the role of coincidence, but in the end, even for Friedrich Engels, coincidence is no more than an appearance of being, of the natural process that necessarily takes place. Engels knew only classical statistics, not quantum statistics. It must be noted that Marx and Engels based their considerations not only on Hegel, but especially also on Charles Darwin, so that they went beyond the Hegelian dialectic in their understanding of dialectic development. The dialectic is not simply a matter of turning Hegel "from head to toe". For the rediscovery of a materialistic, dialectical conception of development, undistorted by pre-deterministic or teleological positions, the development of the theory of irreversible thermodynamics by llya Prigogine and his Brussels school was an important step- that is, the discovery of dissipative structures, which show a self-structuring of matter far from the thermodynamic equilibrium.

Prigogine, a Nobel Prize winner for chemistry, opened up new paths of scientific thinking that bear fruit now also in the social sciences. He explicitly recognises Karl Marx and Friedrich Engels as pioneers in the study of the evolution of nature. Prigogine and Stengers, in their book Order out of Chaos: Man's New Dialogue With Nature, write:

We have described in Chapters V and VI a nature that might be called "historical"-that is, capable of development and innovation. The idea of a history of nature as an integral part of materialism was asserted by Marx and, in greater detail, by Engels. Contemporary developments in physics, the discovery of the constructive role played by irreversibility, have thus raised within the natural sciences a question that has long been asked by materialists (Prigogine and Stengers 1984,252$)$.

With the theory of self-organisation and evolution developed by Peter Glansdorf and Ilya Prigogine (1971), Manfred Eigen (1971), Werner Ebeling (2016, 63-74), Rainer Feistel (Ebeling and Feistel 2014, 141-184) and other students of biophysics, the dialectic of necessity and chance and the dialectic of part and whole have been understood more deeply and the connection between the self-organisation of matter and the creation of biological information has become understandable. 
A generalised, basic process of the evolution to higher forms of the movement of matter can be derived from self-organisation theory. Due to its internal contradictions, matter is constantly creating new possibilities for development. At the lower levels, these developmental possibilities are affected by limiting conditions, for example through specific structures, informational couplings, partial-whole relationships, and selection processes. But what appears as a limitation at lower levels, at higher levels opens up new development possibilities.

A particular example is that whereas thermodynamically many chemical reactions are possible, only extremely specific chemical processes are realised in the living organism. The field of possibilities spanned by the physical-chemical laws is restricted and thus opens up on a higher level the possibilities of biological evolution. At the lower level, however, pre-conditions for this qualitative change are also created. Without these pre-preconditions the qualitative change could not be explained. The new does not come out of nothing.

\section{Neither a Physicalist nor a Vitalistic Theory of Biology}

\subsection{Stricter Internal Determination Through Informational Coupling as Basis for the Specific Quality of the Living}

For theories and modelling in biology, an accurate understanding of the relationship between physics, chemistry, and biology is the essential challenge. In Dialectics of Nature, Engels understands these relationships in the following manner:

Physiology is, of course, the physics and especially the chemistry of the living body, but with that it ceases to be specially chemistry: on the one hand its domain becomes restricted but, on the other hand, inside this domain it becomes raised to a higher power (Engels 1925, 535).

With Engels's approach a possible basis emerges for a neither mechanistic nor physicalist nor vitalistic understanding of the relationship between physics, chemistry, and biology, to overcome the so-called mechanism vitalism controversy. This controversy has already been raging for centuries in philosophy and biology and, with the successes of molecular biology and research in the field of artificial intelligence, has flared up again today.

Physiology is, as Engels says, physics and especially chemistry, but it limits its perimeter and rises to a higher potency. We can today say: Life is physics and chemistry organised by information. Information is understood as effects organising effect.

Today, especially on the basis of the work on the self-organisation of matter of the Brussels School around Prigogine and the molecular Darwinian theory of the origin of life of Manfred Eigen, the analysis of the origin of macromolecules and thus of the origin of biological information can be made much more precise.

The revolution in biology since the middle of the last century was primarily determined by the fact that the elementary foundations of biological processes became accessible to analysis and synthesis. There is a far-reaching analogy with the revolution in physics at the beginning of the last century.

The ancient questions "What is life?", "What is its specificity?", "How is life determined?", and "Through what processes (mechanisms) is the quality of life created?" are today the subject of research that used modern methods of molecular biology (Fuchs-Kittowski, Rosenthal and Rosenthal 2005, 149-162; 219-234). 
Not only many biologists, biochemists and molecular biologists, but also philosophers saw this successful scientific development as a victory for reductionism or physicalism. However, this proved to be a misjudgement. Complex life processes can be traced back to the elementary structures and processes on which they are based, since the macromolecules and their interactions are components of these life processes, but the available knowledge is usually insufficient for understanding the whole.

Just as the quantum physicist learned that the images of wave and corpuscle interaction modify each other, the biologist had to learn that the organism cannot simply be disassembled into its parts and then put back together again like a machine. If we start from the whole and proceed to analyse the parts, something is lost that cannot be recovered simply by putting the parts together. The whole, the organisation of the living, modifies the parts, so in reverse the elementary processes underlying the whole are the bearers of the organisation, the components of the whole. Thus, when we study the processes of life, we are dealing neither with a purely physical-chemical process nor with a purely biological process of some kind. Life is neither a purely physical machine nor a purely biological event, detached from physics and chemistry, but a third phenomenon. From the outset, we are dealing with specific biological processes. We confront ourselves today with descriptive models of automation technology, e.g. with artificial neural networks. We must be aware, however, that these models must be extended or modified if we really want to grasp the new developmental possibilities of matter, which result from the restriction of the possibilities given by the laws of physics and chemistry by the organic whole.

Therefore, we deliberately do not speak of complementarity here, but rather of the modification of the physico-chemical processes by the conditions restricting the physico-chemical processes, such as specific structures, informational coupling, and wholepart relationships. This is expressed as follows: everything that is biologically possible must be physically possible too, but the reverse is not true. Not everything that is physically possible is also biologically possible, for example a rotten egg (Fuchs 1972, 410417). In addition, there are the restricting conditions posed by the possibilities of physical-chemical laws.

In a living (dialectical) whole, in contrast to the mechanical whole of a computer, the relations of the whole to its parts and thus a substantial determination is lost if one limits oneself to the analysis of the parts and their interrelationships. For these do not result from this order and organisation but from the overall organisation. These relations and interactions, especially the effect of the whole on its parts, cannot be disregarded.

\subsection{The Evolution of the Human Being}

\subsubsection{Stronger Inner Determination Caused by the Free Will of the Human Being}

With the capacity for semantic information processing, with the development of human language as an instrument of symbolic knowledge about objective reality, our knowledge became transferable and the possibility of social transmission developed. In addition to biological evolution based on biological inheritance, social evolution based on the transmission of social experience arose, and it is no longer necessary to experience everything oneself in order to understand a certain fact.

Biological evolution is based on the selection of genetic structures through reproductive success. Human evolution is based on the social transmission of knowledge that is effective in tools or in the differentiation of work organisation. The possibility of 
alienating or objectifying information leads to this comparatively rapid social development.

Even if the human being cannot escape the effects of biological evolution, the latter is increasingly receding into the background as a determinant. Acclimatisation of humans to their environment is achieved not so much by changing the genetic make-up of humankind, but rather by changing the environment and redesigning it to suit human purposes. "With man", says Engels,

we enter history. Animals also have a history, that of their descent and gradual evolution to their present position. This history, however, is made for them, and in so far as they themselves take part in it, this occurs without their knowledge and desire. On the other hand, the more the human beings become removed from animals in the narrower sense of the word, the more they make their history themselves, consciously, the less becomes the influence of unforeseen effects and uncontrolled Introduction forces on this history, and the more accurately does the historical result correspond to the aim laid down in advance (Engels 1925, 330-331).

The qualitative change is achieved by a new degree of freedom. In place of the reflex actions and the automatic behaviour of animals, in human beings there is conscious decision-making and conscious self-control. Humans can also display behaviour similar to that of automatons through practiced conditional reflexes or rules imposed from the outside. By conscious decisions and conscious self-control, they can overcome machine-like behaviour and behaviours that correspond to them more as animals than as social human beings.

\section{The Danger of Anti-Dialectical Thinking and of Modern Forms of Reductionism in Our Time}

\subsection{Against the Reification and the Degradation of the Living}

Living organisms and their usefulness are so impressive that many people see them as the expression of a planning and ordering force, proof of the existence of a first intelligent designer. Scientific method, however, has at is centre the assumption that nature existed before humans and humans before the natural sciences, and that there has been a development towards qualitatively higher forms of organisation of matter that are neither predestined nor foreplaned. This is where the natural differs fundamentally from the artificial. However, a theory of evolution is repeatedly distorted by predeterminism and teleological conceptions.

Engels writes in his work "Ludwig Feuerbach and the End of Classical German Philosophy" that

the materialism of the last century was predominantly mechanical [...] This application exclusively of the standards of mechanics to processes of a chemical and organic nature - in which processes the laws of mechanics are, indeed, also valid, but are pushed into the background by other, higher laws - constitutes one specific, but at that time inevitable, limitation of classical French materialism. The other specific limitation of this materialism lay in its inability to comprehend the world as a process, as matter undergoing uninterrupted historical development. This accorded with the state of the natural science of that time, and with the metaphysical, that is, anti-dialectical manner of philosophizing 
connected with it. Nature, so much was known, was in eternal motion. But according to the ideas of that time, this motion turned just as eternally in a circle and therefore never moved from the spot: it produced the same results over and over again. This conception was at that time inevitable (Engels 1888, 370).

Mechanistic, reductionist thinking, which disregards evolution and forgets the specific quality of life, becomes inhuman. This is especially an issue today, when digitalisation and the and use of computers and computer networks permeate all areas of our lives.

The reduction of human beings to animals, and the subsequent implied inferiority of certain human groups in biological and spiritual terms, was the key ideology behind both world wars. Humans reduced to a machine: the widespread postulate nowadays that automata can become superior beings contributed to the degradation of human beings and thus to racism and anti-Semitism, and today pose the threat of the next world war.

Life, with its unique, highly complex structure, is exposed to many dangers including, as many authors point out, changes in external conditions such as the greenhouse effect, but also and perhaps even more so a reductionist scientific and technical view of living and creativity. It is important to stress that it is not the discovery of nuclear fission and DNA, nor decoding of the human genome, nor the development of computers and now global digital networks - the Internet and the Internet of Things - that constitute this threat to our world. Rather, it is the degradation of the living, regarding everything and everyone as a usable resource to be treated accordingly. This ruthless urge to exploit, by which every new scientific hypothesis is immediately tested for its application and potential for profit, broadly characterises the current zeitgeist.

It is a legitimate aim of bio-medical research to uncover the causes of diseases which are still incurable today, such as Alzheimer's disease, cancer and Parkinson's disease, and to seek ways of curing them. Interventions in these complex life events are not hubristic. However, overambitious or misleading promulgation of scientific theory or intent as fact (e.g. untested COVID drugs), or the hasty introduction of new products driven by corporate greed, are violations of human rights, exploitative and display contempt for humanity.

It is the responsibility of science and scientists to ensure that important scientifictechnical developments, currently and especially in computer science and biology, are not misused and neither underestimate nor disregard the complexity and individuality of human beings.

The philosophy of mechanistic materialism, one outcome in the name of the great successes in modern science in biology and computer science, has also fed religious fundamentalist movements. If one defines the mind only as an information processor, reduced to signal processing or syntactic information processing, where science is distorted to show that humans and the computer are identical, and the mind is only hardware or wetware, neuronal connections (Crick 1994) or connections of small robots (Dennett 2005), we should not be surprised that a wish for an "intelligent designer" or a charismatic, authoritarian leader emerges in poor countries with few human prospects and even in rich countries where prospects for many decrease. The result is the wish for an "intelligent designer" (Numbers 2006). Even in Europe we now have mass movements based on fundamentalist, racist, fascist ideas. These movements despise rational thought and propagate acting based on feelings and ideology.

The reduction of humans to the machine, the currently widespread postulate that automata could even become better humans and a post-biological age could dawn, that human society could be replaced by an automated society, as argued by MIT robot 
developer Hans Moravec in his book Mind Children (Moravec 1990), can lead to the complete destruction of humanity. Even false ideas have power, as Joseph Weizenbaum (1976; 2001) and Benno Müller-Hill (1981) never tired of reminding us.

\subsection{Information Creation: An Essential Category for Model and Theory Development and as a General Guiding Principle of Methodology}

Reductionism in science as an ideological attitude can effectively be countered by working out the specifics of the living, especially the living in relation to the dead and the human being in relation to the technical automaton or autonomous robot. Weizenbaum asked Moravec whether he really thought that he could transfer the truly human, e.g. a smile of a young mother to her child, to robots. (Fuchs-Kittowski and Wenzlaff 1987, 502-511).

The learning automaton, such as the vehicle robot for so-called autonomous driving, receives its information and value system from the outside. As Eigen (1972, 171223), showed in his Darwin-based theory of the origin of life, the information and value systems must originate internally (Fuchs-Kittowski and Rosenthal 1972, 308-313).

The category of information creation proved essential in model and theory formation towards understanding the origin of life in the border area between physics, chemistry, and biology. Wherever functions need to be newly created and organised, new information and evaluations are required. Therefore, the category of information creation is as essential for the understanding of phylogenesis and ontogenesis, as well as for model and theory formation in the border area between computers (software) and the human mind, as well as between automaton-supported information systems (application systems) and creative learning social organisations. It is part of the responsibility of science, especially in biology and computer science theory, to bring this specificity of the living and humanity to bear, because this is the only way to guard against the degradation of humans through the automaton as well as to prevent further forms of discrimination.

There ae scientific-theoretical and methodological implications of the concept of creativity. The creation of information has gained in importance for almost all areas of scientific interest (Fuchs-Kittowski 2014; Hofkirchner 2011). In particular, there is methodological evidence for safer navigation between the Scylla of gross reductionism, inspired by $19^{\text {th }}$ century physics and $20^{\text {th }}$ century neurophilosophy and connectionist $\mathrm{Al}$ research that propagate a mind-brain identity, and the Charybdis of dualism, inspired by the vitalism of $19^{\text {th }}$ century Romanticism and the $20^{\text {th }}$ century functionalist bodymind or hardware-software duality of cognitivist Al research.

The basis for post-humanistic and other anti-humanistic concepts is the reduction of the human being to an information system and the reduction of information to its syntactic structure. This accords with the information processing approach of classical Al research. The central role of creativity, the origin of information in the living, in innovative thought and the develop of social organisations, helps us understand humancomputer interaction as a coupling of machine (syntactic) information processing with the creatively active human being that is capable of semantic information processing. In this way the goal of automation is not super automation, i.e. the complete replacement of humans. Humanity requires the meaningful coupling of the specific abilities of computers and humans so that anti-human ideas lose theoretical and practical ground (Fuchs-Kittowski 1981, 275-285; Fuchs-Kittowski 2006, 431-444; Fuchs-Kittowski 2016, 10-2). 


\section{The Evolution of Society}

\subsection{Stronger Determination of Social Processes Through the Conscious Organisation of Social Production}

Only the conscious organisation of production enables the human to be a human being. Friedrich Engels writes in his work Dialectics of Nature that

only conscious organisation of social production, in which production and distribution are carried on in a planned way, can lift mankind above the rest of the animal world as regards the social aspect, in the same way that production in general has done this for mankind in the specifically biological aspect. Historical development makes such an organisation daily more indispensable, but also with every day more possible (Engels 1925, 331).

This resonates with us today. One reason is that software development accelerates the objectification of mind. The objectification of mind in software by means of machineprocessable syntactic structures leads to the socialisation of knowledge. For example, the knowledge worker has the skills of the previous typist at his or her disposal and the skills of a translator, and the experimental physicist has the physical theory at his or her disposal. The more mental expression or objectification increases, the less intellectual follow-up of the objectified, social processes is necessary and feasible, the more human individuality is set free and can become an essential factor in human development.

When the intellectual and practical follow-up of human activities is less and less necessary or feasible, however, there is also the danger of a decline of abilities and that humans are left behind (Carr 2014). In capitalist society, the socialisation of knowledge through its objectification in software also increases the contradiction between societal production and private appropriation (Fuchs 2014, 2020).

Right now, therefore, the aim must be to counteract the monopoly power of the large digital platform providers, whose business models build behavioural profiles over large parts of the world's population. This new capitalism, called "surveillance capitalism" by Shoshana Zuboff (2019), works by providing free services that are happily used by billions of people. It can enable providers of these services to change the behaviour of these users in astonishing and often very precise ways, often without their explicit consent. Behavioural predictions secretly derived from user monitoring are exploited (Landwehr, Borning and Wulf 2019).

As Die Welt am Sonntag (19 April 2020, 32) recently reported, we are today in a "near-total dependence on Amazon's cloud". Legal regulations are needed to counter the power of such super monopolies, the dominance of their platforms and the associated social models. In addition, Europe needs to create its own software-orgware system and IT infrastructures that are keeping up and advancing the tradition of European work culture. Real social transformation is necessary today (Fuchs-Kittowski 2020, 83113)

For Marx, the decisive factor of automation as a social process is not the oftenquoted withdrawal of humans from the immediate production process. This is only the external site of the automation process. For Marx, the essence of automation as a social process consists in "the free development of individuality" (Marx 1857/1858, 706), based on "the appropriation of his [the individual's] own general productive power" (Marx 1857/1858, 705).

Marx (1857/1858, 705) wrote: 
In this transformation, it is neither the direct human labour he himself performs, nor the time during which he works, but rather the appropriation of his own general productive power, his understanding of nature and his mastery over it by virtue of his presence as a social body - it is, in a word, the development of the social individual which appears as the great foundation-stone of production and of wealth.

The insight that captures the essence of the process of digitalisation and automation is therefore that through the integration of machine operations into the individual activity of the human being a directly productive appropriation of all those objectified creative forces of human society takes place, leading to these automated operations. For this appropriation one needs of course more free time, which requires the full development of the individual, but also the individual's possibility of becoming the owner and determiner of his or her own general productive force.

\subsection{Human Emancipation}

According to our thesis that every transition to a higher form of movement of matter is based on a stronger inner determination, rooted in the nature of the carriers of the relevant form of movement, the transition to the social form of movement of matter and its further development is increasingly determined by the nature of the human being, to be a human being among human beings. As with the emergence of life through the dialectical relationship between the biological whole and its parts, a further determining factor occurs here. Conscious decision-making and conscious self-control are all the more effective the more comprehensive the knowledge of the laws of nature and society, and the deeper the understanding of fellow humans and the self as social being.

People can behave like animals but do not have to. People can behave like computers but do not have to. The free will and inner determination of human beings can be powerfu. (Fuchs-Kittowski 2013, 41-42).

The humanist and critical spirit of the Enlightenment, carried forward to our humanism of today, means that human progress consists not only in a growing mastery of the forces of nature and society, but also in achieving new levels of self-understanding and thus new dimensions of human freedom.

Insight into the necessity of the external conditions that a person must understand in order to transform them according to their own needs and desires provides the means to fulfil needs and desires, but not the deeper goal of this effort. The deeper goal is the awareness that we all are human beings among other human beings. The insight into the inner necessity as a human being enables working for the creation of a society humans deserve. It can, like the brave antifascists in the concentration camps set up by the Nazis, provide the strength not to break down in the face of external adversities. That is true autonomy!

In his work "On the Jewish Question", Marx writes that it is wrong to reduce human emancipation to no more than the political objective of the French Revolution - the "free state" rather than free humanity. He says:

All emancipation is a reduction of the human world and relationships to man himself. [...] Only when the real, individual man re-absorbs in himself the abstract citizen, and as an individual human being has become a species-being in his everyday life, in his particular work, and in his particular situation, only when man has recognized and organized his 'forces propers' [own powers] as social powers, and, consequently, no longer separates social power from himself in 
the shape of political power, only then will human emancipation have been accomplished (Marx 1844, 168).

Marx and Engels' argument that all emancipation is the return of the human world to the human being itself extends Hegel's concept of Becoming Subject. This concept requires not just a theoretical understanding but is about the design of social production. Only thus is human emancipation achieved.

In this conception of society, concrete humans, united subjects in their consciously designed frameworks, will not be angels. Internal contradictions will drive further developments. But there is always the hope that the contradictions of a society driven by profit will be overcome. It is therefore necessary that humans actively and consciously shape social processes and do so self-confidently and with purpose. This could transform still largely unreasonable social practices into a rational way of living together that realises concrete humanism.

\subsection{A World Without War Is and Must Be Possible!}

The fundamental vision connected with the development of cybernetics and now with the development of global, digital networks is that of a world of people communicating with each other (as Norbert Wiener and J.C.R. Licklider pointed out), as a basis for a "world without war" (see Hauben and Hauben 1997; Hauben 2004, 267-281). Today, however, we experience the opposite. Digital networks have become the basis for cyberwars. It is important to remember how important the end of the Cold War was, and how dangerous it is that humans are already talking about the beginning of a new Cold War or, as Horst Teltschik, Helmut Kohl's foreign policy advisor, puts it, to slide "From the Cold War to the Cold Peace" (Teltschik 2019). A key perception in Teltschik's book is that during the Cold War there was always a diplomatic connection to a wider world, in the then shape of the Soviet Union. Today our increasingly fragmented world and growing nationalism in various countries brings with it greater and greater isolation.

This situation is an example of how in evolution and also in the history of humankind, opportunities that arise are missed. After the end of the Cold War there was a real possibility of disarmament. The vision of the "common house of Europe" seemed to be generally accepted. This great opportunity appears so far to have vanished.

Such developments should serve as a reminder to us that there is not only continuous development, but also regression. As Engels wrote, "according to Hegel, infinite progress is a barren waste because it appears only as eternal repetition of the same thing: $1+1+1$, etc. In reality, however, it is no repetition, but a development, an advance or regression, and thereby it becomes a necessary form of motion." (Engels 1925, 517)

There is the real possibility of creating a better society, but also the real possibility of cyberwar and nuclear war. Therefore, it is necessary to recall the historical experience of the small steps in understanding that were crucial in ending the Cold War. In the nuclear age it is irrational to regard war as a suitable means of restoring violated rights. In view of the danger of the annihilation of humanity, there is no just war or just revolution that would justify the use of such weapons. Social injustices should be overcome by peaceful means.

There were always people who thought ahead, who had their own thoughts and values. I am convinced that this will also characterise the future generations of humans who will question the given and seek change and who will try to improve the society in which we live. A world without war is and must be possible and also a world will come, 
where the contradictions of past society will be overcome and the free development of the individual becomes the precondition of the free development of all.

\section{References}

Carr, N., Nicolas. 2014. Abgehängt-Wo bleibt der Mensch, wenn Computer entscheiden? Hanser: München.

Crick, Francis. 1994. What the Soul Really Is: The Scientific Investigation of Consciousness. Munich: Artemis \& Winkler.

Dennett, C. Daniel. 2005. Sweet Dreams: The Exploration of Consciousness and the Sleep of Philosophy. Cambridge, MA: The MIT Press.

Ebeling, Werner. 2016. Physik, Biologie, Technik und Selbstorganisation der Information. In Informatik und Gesellschaft - Festschrift zum 80. Geburtstag von Klaus Fuchs-Kittowski, edited by Frank Fuchs-Kittowski, Werner Kriesel. Frankfurt am Main: Peter Lang.

Ebeling, Werner and Rainer Feistel. 2014. Selforganisation of Symbols and Information. In Chaos, Information Processing and Paradoxial Games: To the Memory of John S. Nicolis, edited by Gregoire Nicolis and Vasileios Basios, 141-184. Singapore: World Scientific.

Eigen, Manfred. 1972. Molecular Self-Organization and Evolution. In Informatik, Nova Acta Leopoldine, edited by Joachim-Hermann Scharf, 171-223. Leipzig: Johann Ambrosius Barth.

Eigen, Manfred. 1971. Selforganization of Matter and the Evolution of Biological Macromolecules. Die Naturwissenschaften 58 (10): 465-523.

Engels, Friedrich. 1925. Dialectics of Nature. In Marx \& Engels Collected Works (MECW) Volume 25, 311-588. London: Lawrence \& Wishart.

Engels, Friedrich. 1888. Ludwig Feuerbach and the End of Classical German Philosophy. In Marx \& Engels Collected Works (MECW) Volume 26, 353-398. London: Lawrence \& Wishart.

Engels, Friedrich. 1878. Anti-Dühring. Herr Eugen Dühring's Revolution in Science. In Marx \& Engels Collected Works (MECW) Volume 25, 5-309. London: Lawrence \& Wishart.

Fuchs, Christian. 2020. Marxism: Karl Marx's Fifteen Key Concepts for Cultural and Communication Studies. New York: Routledge.

Fuchs, Christian. 2014. Digital Labour and Karl Marx. New York: Routledge.

Fuchs, Klaus. 1972. Über die Kategorie der Möglichkeit und die Entwicklungsstufen der Materie. Deutsche Zeitschrift für Philosophie 20 (4): 410-417

Fuchs-Kittowski, Klaus. 2020. Zur Verantwortung der Wissenschaft für die Gewährleistung der Menschenrechte - Im Kampf gegen die Degradierung des Menschen, Rassismus und Antisemitismus. In Wissenschaftsforschung, Jahrbuch 2019, edited by Harald Mieg, Hans Lenk, Heinrich Parthey, 112-147. Berlin: Wissenschaftlicher Verlag Berlin.

Fuchs-Kittowski, Klaus. 2018. Zur Entstehung und Erhaltung von Information in lebendiger Organisation - Grundkategorien einer Theorie der Biologie und der Informatik, Vortrag auf dem Kolloquium „Emergente Systeme. Information und Gesellschaft“ am 10.12.2015. Leibniz Online 32 (2018) Zeitschrift der Leibniz-Sozietät e. V. https://leibnizsozietaet.de/wp-content/uploads/2018/03/Fuchs-Kittowski.pdf

Fuchs-Kittowski, Klaus. 2016. Stellung und Verantwortung des Menschen in komplexen informationstechnologischen Systemen in Organisationen, Informationsmanagement, Wirtschaftsinformatik \& Management 8 (2): 10-21.

Fuchs-Kittowski. Klaus. 2014. The Influence of Philosophy on the Understanding of Computing and Information. In Philosophy's Relevance in Information Science, edited by Ruth Hagengruber and Uwe V. Riss, 45-56. London: Pickering \& Chatto.

Fuchs-Kittowski, Klaus. 2013. Ethik und Informatik - Moralität und Historizität - Zur notwendigen Solidarität mit den Whistleblowern, Weltweite Datenausspähung. FlfF-Kommunikation 3: 41-42.

Fuchs-Kittowski, Klaus. 2006. Strategies for an Effective Integration of ICT into Social Organization - Organization of Information Processing and the Necessity of Social Informatics. 
In Social Informatics: And Information Society for ALL? - In Remembrance of Rob Kling, edited by Jacques Berleur, Markku I. Nurminen, John Impagliazzo, 431-444. Heiderlberg: Springer.

Fuchs-Kittowski, Klaus. 1997. Information-Neither Matter nor Mind - On the Essence and on the Evolutionary Conception of Information. World Futures. 50 (1-4): 551-570.

Fuchs-Kittowski, Klaus. 1992. Reflections on the Essence of Information. In Software Development and Reality Construction, edited by Christiane Floyd, Heinz Züllighoven, Reinhard Budde und Reinhard Keil-Slawik, 416-432. New York: Springer Verlag.

Fuchs-Kittowski, Klaus. 1976. Probleme des Determinismus und der Kybernetik in der molekularen Biologie, Tatsachen und Hypothesen über das Verhältnis des technischen Automaten zum lebenden Organismus. Jena: VEB Gustav Fischer Verlag. http://www.max-stirner-archiv-leipzig.de/dokumente/Fuchs-Kittowski-Determinismus.pdf

Fuchs-Kittowki, Klaus and Hans A. Rosenthal. 1972. Self-organisation and Evolution. Wissenschaft und Fortschritt 22 (7): 308-313.

Fuchs-Kittowski, Klaus, Hans A. Rosenthal, and André Rosenthal. 2005. Die Entschlüsselung des Humangenoms - anbivalente Auswirkungen auf Gesellschaft und Wissenschaft. \& Replik: Geistes- und Naturwissenschaften im Dialog Erwägen, Wissen, Ethik (Deliberation- Knowledge - Ethics) Streitforum für Erwägungskultur 16 (2): 149-162, 219-234.

Fuchs-Kittowski, Klaus, Ursula Schuster and Bodo Wenzlaff. 1981. Working Environment Organizational, Technological and Social Problems of Computerization. Sotac'79 (Part I): Computers in Industry 2 (4): 275-285.

Fuchs-Kittowski, Klaus and Bodo Wenzlaff. 1987. Probleme der theoretischen und praktischen Beherrschung der modernen Informations- und Kommunikationstechnologien. Deutsche Zeitschrift für Philosophie 35 (6): 502-511.

Glansdorf, Peter and Ilya Prigogine. 1971. Thermodynamics Theory of Structure, Stability and Fluctuations. London: Wiley-Interscience.

Hartmann, Nikolai. 1935-1950. Ontologie. 4 Bände. Berlin: Walter de Gruyter.

Hauben, Ronda. 2004. Creating the Vision for the Internet, From the Wiener Circles to Licklider and ARPA's Information Processing Techniques Office (IPTO). In Kybernetik und Interdisziplinarität - Georg Klaus zum 90. Geburtstag, Abhandlungen der Leibniz-Sozietät, edited by Klaus Fuchs-Kittowski and Siegfried Piotrowski, 267-281. Berlin: trafo Verlag.

Hauben, Michael and Ronda Hauben. 1997. Netizens: On the History and Impact of Usenet and the Internet. Los Alamitos, NM: IEEE Computer Society Press.

Hofkirchner, Wolfgang. 2011. Emergent Information - A Unified Theory of Information Framework. Singapore: World Scientific.

Landwehr, Marvin, Alan Borning, and Volker Wulf. 2019. The High Cost of Free Services: Problem with Surveillance Capitalism and Possible Alternatives for IT Infrastructure. In LIMITS '19: Proceeding of the Fifth Workshop on Computing Within Limits, article 3. New York: ACM. https://doi.org/10.1145/3338103.3338106

Marx, Karl. 1857-1858. Grundrisse: Foundation of the Critique of Political Economy. London: Penguin.

Marx, Karl. 1844. On the Jewish Question. In Marx \& Engels Collected Works (MECW) Volume 3, 146-174. London: Lawrence \& Wishart.

Moravec, Hans. 1990. Mind Children: The Future of Robot and Human Intelligence. Cambridge, MA: Harvard University Press.

Müller-Hill, Benno. 1981. Die Philosophen und das Lebendige. Frankfurt am Main: Campus.

Numbers, L. Ronald. 2006. The Creationists: From Scientific Creationism to Intelligent Design. Berkeley: University of California Press.

Prigogine, llya and Isabelle Stengers. 1984. Order out of Chaos: Man's New Dialogue With Nature. Toronto: Bantam.

Teltschik, Horst. 2019. Russisches Roulette: Vom Kalten Krieg zum Kalten Frieden. München: C.H. Beck. 
Wahl, Dietrich. 2012. Sein und Selbst: Aus dem wissenschaftlichen Nachlass. Mit einem Essay von Klaus Fuchs-Kittowski: "Information und Selbstorganisation - Erkenntnis und Selbsterkenntnis". Berlin: Rosa-Luxemburg-Stiftung.

Weizenbaum, Joseph. 2001. Computermacht und Gesellschaft. Frankfurt am Main: Suhrkamp.

Weizenbaum, Joseph. 1976. Computer Power and Human Reason: From Judgement to Calculation. San Francisco: W.H. Freeman.

Zuboff, Shoshana. 2019. The Age of Surveillance Capitalism: The Fight for a Human Future at the New Frontier of Power. New York: Public Affairs Books.

\begin{abstract}
About the Author
Klaus Fuchs-Kittowski

Prof. Dr. Phil. Habil. Klaus Fuchs-Kittowski was a Professor of Information Processing at Humboldt University in Berlin. He was born December 31st 1934 in Berlin. He studied philosophy in Leipzig and undertook postgraduate training in biochemistry, biology, the mathematical foundations of cybernetics and philosophy of science at Humboldt University. He earned a PhD in philosophy on the problem of determinism and cybernetics in molecular biology. In 1964 he was among the founders of the University's Computer Center and, in 1968, of its Department of Economical Cybernetics and Operation Research, which later became the Department for Theory and Organization of Science. He was vice Director of the Department and Head of the Division of Information System Design and Automated Information Processing. In 1972, he was awarded the Rudolf Virchow Prize for medical research. He collaborated with the IIASAgroup on Modelling of Healthcare Systems and on Data-Communication. He became a member of IFIP/TC9 (International Federation of Information Processing, Technical Committee 9 Interaction of Computer and Society). For six years he was Chairman of the "Computer and Work" Working Group 1 of the IFIP/TC9. For this work, he received the IFIP Silver Core. In 1989, Fuchs-Kittowski had the opportunity of working on a project on Evolution of Information Structures led by Peter Fleissner at the Vienna University of Technology. Fuchs-Kittowski was Visiting Professor at the Department of Informatics at the University of Hamburg and Visiting Professor at the Department of Economical Informatics of the Johannes Kepler University in Linz. He currently teaches at the University of Applied Sciences (HTW) Berlin in the field of Environmental Informatics and Society.
\end{abstract}

